\title{
Is Board Independence a Panacea for Improved Corporate Performance? Evidence in a Developing Country Setting
}

\author{
Suren Peter \\ Department of Industrial Management, University of Kelaniya, Sri Lanka
}

\begin{abstract}
Corporate governance was brought back into the limelight over the last decade, with the large number of dramatic corporate collapses around the world which drove some of the financial giants in the finance industry to bankruptcy. The need to revisit the mechanism for monitoring governance, especially since many of the big scandals emanated from the West, where a culture of good corporate governance was seemingly embedded in the corporates. The board of directors has long been recognized as the primary and dominant internal corporate governance mechanism for aligning the interests of managers and all stakeholders to a firm. Separation of ownership from management raises a key issue of how to effectively monitor managers to ensure that they act in the best interest of the shareholders and other stakeholders as well. The role of independent directors in improving the effectiveness of control has been the subject of debate in academic literature, especially in the context of a developing country where unlike in the developed economies, a culture of poor corporate governance is the norm rather than the exception. The paper explores this issue, paying particular attention on the relationship between corporate board independence and firms' financial performance in a development country setting. Using data obtained from Colombo Stock Exchange, Sri Lanka for the period 2004 through 2009, a sample consisting of fifty firms were used to assess board independence and their impact on performance. Data was gathered through published reports and a primary survey. Independence of the board was deconstructed to board composition as measured by proportion of independent directors and proportion of non-executive directors. The firm performance was measured using both financial and market performance indicators. After controlling for industry, firm size and CEO duality, the results indicate support for stewardship perspective, with no convincing evidence to indicate that inclusion of independent directors is associated with improved financial performance. The weak governance structure which could be exemplified by ownership entrenchment, cross sitting of board members and lack of cumulative voting may explain the lack of evidence found. However, the results indicate that inclusion of independent directors is valued by investors and reflected in enhanced firm value.
\end{abstract}

Keywords: Board independence, corporate governance, performance

DOI: $10.7176 / \mathrm{EJBM} / 12-33-06$

Publication date: November $30^{\text {th }} 2020$

\section{Introduction}

The concept of corporate governance has been a priority on the policy agenda in developed market economies for over a decade especially among very large firms. Companies have long recognized that good governance generates positive returns to a firm and boost confidence. Effective internal and external corporate governance practices are important to establish an efficient and effective organization that is transparent and fair to all stakeholders. Without it organizations are characterized by corruption or nepotism. Poorly governed firms are expected to be less profitable, prone to bankruptcy, lower valuations and pay out less to their shareholders. The last decade and a half has seen the world go through financial turmoil primarily attributed to poor governance, among others factors. The turmoil seen in the financial markets, strangely originated from the USA and then spread to some of the developed economies in the western world, where the practice of good corporate governance is well embedded. On the other hand, in the developing economies in the world, such governance mechanisms, are either non-existent in some extreme cases, or poorly enforced in many others. The governance mechanisms that have been put into place in these developing markets, are those implemented in the west. Given the small market size, poor regulation, inadequate enforcement, legal environment among others, it would be interesting to assess, whether the solutions espoused by the developed markets, assist in improving governance in these markets.

The board of directors has long been recognized as the primary and dominant internal corporate governance mechanism for aligning the interests of managers and all stakeholders to a firm. The need to adopt the right corporate governance mechanisms for the purpose of such alignment is driven by the agency problem and the associated free-rider problem that makes it difficult for any single investor or stakeholder to bear the cost of monitoring managers. Therefore, the central role of board of directors and its independence in this process has therefore been recognized and in recent years has gained significant attraction. In establishing proper governance, independence and transparency, independent directors are entitled to play a key role while supervising and giving strategic guidelines to the management (Jonsson, 2005). Therefore, role of independent directors in improving the effectiveness of control has been the subject of lengthy discussions both in academic literature and in the business world. While regulations to improve corporate governance have been ongoing, the large number of corporate 
collapses around the world has led to the discussion whether the mechanisms suggested to improve governance has been really effective in increasing firm performance. The changes in board composition to have non-executive or non-executive independent directors are being questioned as to whether they are effective tools in monitoring and improving performance of the firm. This issue of effectiveness of board independence has received significant attention and is of wide interest within the context of many developed countries. The apparent premise underlying the appointment of non-executive independent directors is presumably to lead to improved corporate governance and increased shareholders' wealth and firm performance. The results are mixed with some studies suggesting that independent non-executive directors can enhance shareholders' wealth and firm performance (Joh \& Jung, 2012; Barnhart et al., 1998; Rosenstein and Wyatt, 1990), while others found that in fact there is no influence on firm performance (Rashid, 2018; Fuzia et al., 2016; Rashid et al., 2012). The issue on how effective these measures are in the context of developing countries with a history of poor corporate governance regulation and enforcement is evaluated in the context of firms listed on the Colombo Stock Exchange (CSE) in Sri Lanka. The study examines whether the appointment of non-executive and non-executive independent directors had its desired effect in enhancing firm performance in the context of a developing economy like Sri Lanka.

\section{Literature review}

Corporate governance refers to structures and processes established for directing and controlling companies (Cadbury, 1992). Collectively, these constitute a set of rules that govern the relationships among management, company shareholders, and other stakeholders including consumers, creditors, employees, the general public, neighboring people and suppliers. The rules of corporate governance aim to ensure that managers act in the best interests of their shareholders rather than simply acting in their own interests or those of a majority shareholder. Agency theory, stewardship theory, resource dependency theory and stakeholder theory among others provide a theoretical perspective to explain corporate governance and its' related issues. In agency theory, the fundamental premise is that the managers' act out of self-interest and are self-centered, thereby, giving less attention to shareholder interests. Managers who possess superior knowledge and expertise about the firm are in a position to pursue self-interests rather than shareholder interests (Fama, 1980; Fama \& Jensen, 1983b). Shareholder interests can clearly be compromised if managers maximize their self-interest at the expense of organizational profitability, i.e., the managers expropriating shareholder's interests. In essence, the tendency is for managers to expropriate shareholder interests and thus cannot be trusted and need to be monitored. Monitoring of management activities is seen as a fundamental duty of a board, especially where ownership is widely dispersed with insufficient payoff for small shareholders to expend resources to monitor themselves.

Stewardship theory takes a diametrically opposite perspective to the agency perspective. It suggests that agents are essentially trustworthy and good stewards of the resources entrusted to them, which makes monitoring redundant (Subramanian, 2018; Donaldson \& Davis, 1994). The stewardship perspective views directors and managers as stewards of firm. As stewards, directors are likely to maximise the shareholders' wealth. Davis et al. (1997) posit how stewards derive a greater utility from satisfying organizational goals than through self-serving behaviour. They argue that the attainment of organisational success also satisfies the personal needs of the stewards. Stewardship theory suggests that managers should be given autonomy based on trust, which minimizes the cost of monitoring and controlling behaviour of the managers and directors. When managers have served a firm for considerable period, there is a "merging of individual ego and the corporation" (Donaldson \& Davis, 1991). Stewardship theory considers that manager's decisions are also influenced by nonfinancial motives, such as need for achievement and recognition, the intrinsic satisfaction of successful performance, plus respect for authority and the work ethic. From the stewardship theory perspective, superior performance of the firm was linked to having a majority of the inside (executive) directors on the board since these inside directors (managers) better understand the business, are better placed to govern than outside directors, and can therefore make superior decisions (Donaldson, 1990; Donaldson \& Davis, 1991). Stewardship theory argues that the effective control held by professional managers empowers them to maximize firm performance and corporate profits. Consequently, insider-dominated boards are favored for their depth of knowledge, access to current operating information, technical expertise and commitment to the firm. Similarly, CEO duality (i.e., same person holding the position of Chair and the chief executive) is viewed favorably as it leads to better firm performance due to clear and unified leadership (Donaldson \& Davis, 1991; Davis, et al., 1997).

Resource dependence theory provides a theoretical foundation for the role of board of directors as a resource to the firm (Hillman et al., 2000; Johnson et al., 1996). Penrose (1995) stressed the importance of unique bundles of resources a firm controls that are crucial for its growth. Such resources include all assets, capabilities, organizational processes, firm attributes, information, and knowledge controlled by a firm, in order to improve efficiency and effectiveness (Daft, 2006). From this point of view, firm governance structure and the board composition is viewed as a resource that can add value to the firm. Organizations attempt to exert control over their environment by co-opting the resources needed to survive (Pfeffer \& Salancik, 1978). Accordingly, boards are considered as a link between the firm and the essential resources that a firm needs from the external 
environment for superior performance. Appointment of outsiders on the board helps in gaining access to resources critical to firm success (Johnson et al., 1996). In the resource dependence role, outside directors "bring resources to the firm, such as information, skills, access to key constituents (e.g., suppliers, buyers, public policy decision makers, social groups) and legitimacy" (Hillman et al., 2000). Pfeffer \& Salancik (1978) showed that the board size and background of outside directors are important to managing an organisation's needs for capital and the regulatory environment. Scholars have also used resource dependence theory to explain the composition of boards, especially in terms of outsider representation. Kaplan and Minton (1994) find poor financial or stock market performance of a firm often leads to appointment of financial directors to the board. Hermalin and Weishbach (1988) also find that inside directors are replaced with experienced outsiders, when the firm performance is poor. Further, Pearce and Zahra (1992) find that outsiders are appointed on the board in order to bring a fresh perspective when the firm is not doing well.

Stakeholder theory is an extension of the agency view, which expects board of directors to take care of the interests of shareholders. However, this narrow focus on shareholders has undergone a change and boards are now expected to take into account the interests of many different stakeholder groups, including interest groups linked to social, environmental and ethical considerations (Donaldson \& Preston, 1995; Freeman, 1984). Stakeholder theory views that "companies and society are interdependent and therefore the corporation serves a broader social purpose than its responsibilities to shareholders" (Kiel \& Nicholson, 2003).

The study considers that due to the separation of ownership and control, the agent may be driven by selfinterest. The board composition in the form of representation of outside independent directors will be able to provide important monitoring functions in an attempt to resolve the agency conflict between management and shareholders (Bathala and Rao, 1995). Considering the Resource Dependence Theory, appointment of outsiders on the board will help in gaining access to resources critical to firm success (Johnson et al., 1996). For example, the outside links and networks that board members exercise may positively benefit the development of business and long-term prospects. Therefore, this study is conducted within both agency and Resource Dependence theory perspectives. The general validity of these theories can also be better made on firms that have different corporate governance mechanisms.

Given the problems in mitigating agency problems through the use of contracts, scholars have suggested various governance mechanisms to address the agency problems. Agency theory thus provides a basis for firm governance through the use of internal and external mechanisms (Roberts et al., 2005; Weir et al., 2002). The governance mechanisms are designed to "protect shareholder interests, minimise agency costs and ensure agentprincipal interest alignment" (Davis et al., 1997). Two important internal governance mechanisms used for this purpose are board of directors and compensation schemes to align the interests of both the agent and the principal. Fama (1980) considers the board a low-cost mechanism of management compared to other alternatives such as, for example, takeovers. The literature on board, as a governance team, is mainly focused on issues such as board size, and executive versus non-executive directors, separation of CEO and Chair positions (Daily et al., 2003; Coles \& Hesterly, 2000) with an aim to improve the effectiveness of oversight.

An extensive literature has examined the relationship between the composition of the board of directors and different proxies for corporate performance. Main approaches to measuring board composition have been identified: executive directors, non-executive directors (non-independent), independent non-executive directors (Anderseen and Reeb 2004; Daily et al. 1993; Hermalin and Weisbach, 2003). The independent directors may be best able to fulfill the control role since they are not encumbered by personal and/or professional relationships with firm management. Therefore, many believe that independent directors would be more likely to monitor and perhaps challenge management if needed. 


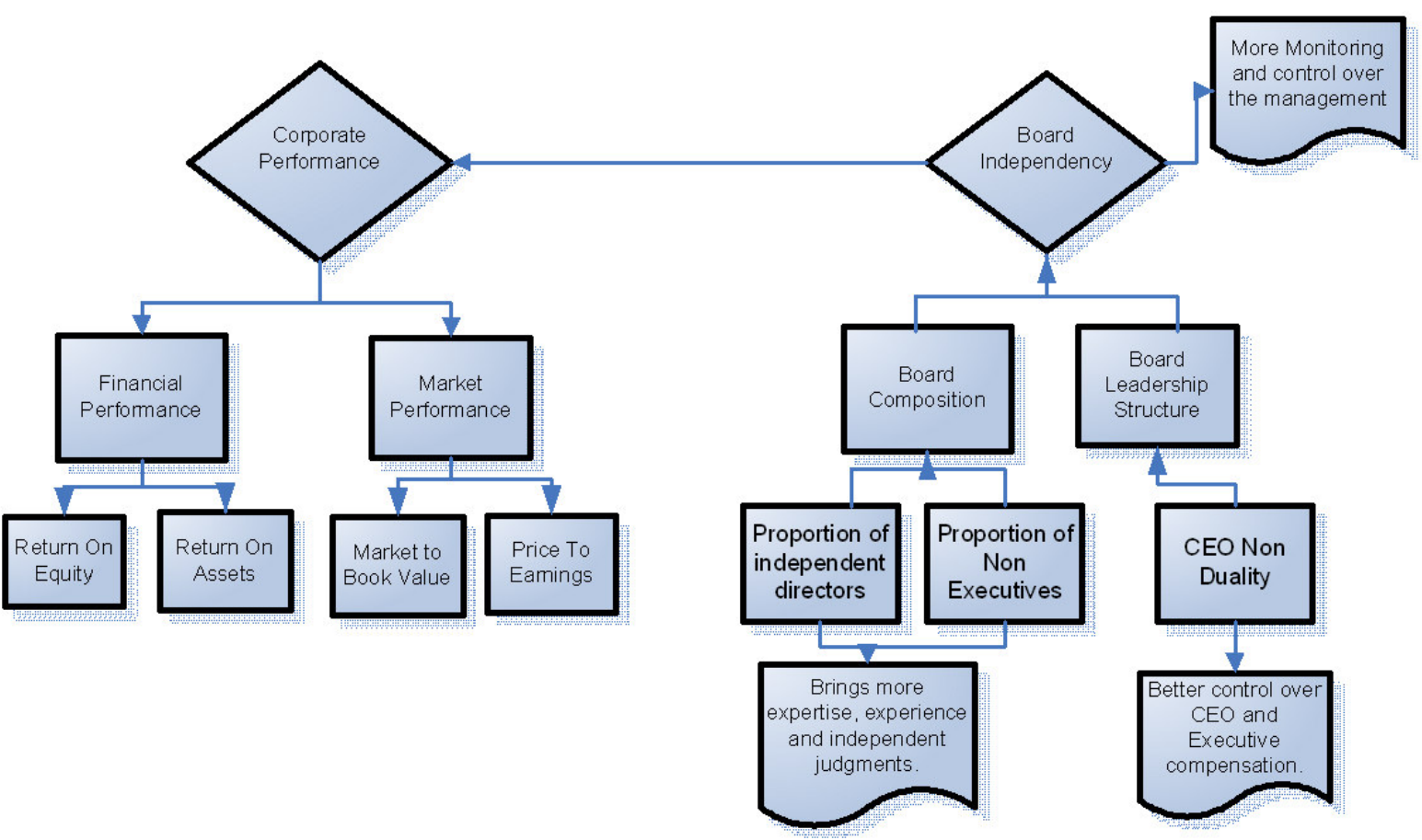

Figure 1. Conceptual framework - Board independence and corporate performance

When considering firms' performance, it's reflected mainly through accounting measures. However, the accounting measures capture only historical aspects of firm performance (McGuire et al., 1988) and they are subject to bias from managerial manipulation and differences in accounting procedures (Brilloff, 1972). Market measures on the other hand, are forward looking and focus on market performance. They are less susceptible to different accounting procedures and represent the investor's evaluation of the ability of a firm to generate future economic earnings. Therefore, both accounting and market performance are important when measuring firm performance.

Figure 1 presents the conceptual framework of the study based on agency theory perspective. As shown the major influencing factors for board independence under consideration would be the board composition and board leadership structure which ensure better monitoring and control over the management which should drive superior financial and market performance.

However, many listed firms in the country had already adopted the non-duality CEO structure. Therefore, the focus in this study was the board composition in the form of non-executive directors and independent, nonexecutive directors. Therefore, in order to control the effect of leadership structure, only the firms with non-dual CEO structure were selected for the study.

The focus on board independence is grounded in agency theory, which addresses inefficiencies that arise from the separation of ownership and control (Fama, 1980; Fama and Jensen, 1983a; Jensen and Meckling, 1976). From the agency theory perspective, boards of directors (and particularly independent non-executive directors) are put in place to monitor managers on behalf of shareholders (Lynall et al., 2003). The literature on the relation between board independence (as a corporate governance device) and firm performance has registered significant growth. In the last decade, a number of empirical studies has been carried out to investigate the impact of board composition on firm performance (Martin and Herrero, 2018; McIntyre et al., 2007; Fan et al., 2007; Ponnu, 2008). Despite this, the relationship between corporate boards and firm performance, especially on the effects of board independence on firm performance, are still mixed.

\section{Methodology}

The sample for the research has been drawn from firms listed in the Colombo Stock Exchange (CSE) during the six year period (2004 - 2009). The study primarily uses secondary data which have been collected from audited company annual reports supplemented by other secondary information made available through CSE. The initial sample frame consisted of all 234 listed firms on the CSE, under 20 different sectors. However, all financial and utility firms were excluded from the analysis since they are fundamentally different from firms in other industries and subject to a different regulatory framework, while their gearing structure is also fundamentally different to companies in other sectors (Dimitrov and Jain, 2008). In order to control for firm size and maturity of the firm, only the firms with market capitalization close or above one billion rupees have been considered for the analysis. Further, all the firms taken into analysis have more than fifteen years of existence in the industry. Finally, in order 
to control for other external factors affecting performance of the firm, similar size firms with similar set of product and services were considered within a particular sector. The final sample consisted of 50 companies listed in the Colombo Stock Exchange, representing 9 major sectors and 13 sub sectors. The study involved examining the impact of board composition on firm's financial performance. The governance element being the independent variable and performance variable being the dependent variable is initially tested to record any relationship. Average performance and composition variables are used since governance is a long-term phenomenon whose effects may be spread over different periods. Board independence was measured by proportion of non-executive directors sitting on the board and proportion of independent non-executive directors sitting on the board. The firms' financial performance was captured through return on assets and return on equity, while market performance was assessed through market to book value ratio (MBVR) and price to earnings ratio.

\subsection{Executive \& non-executive directors and firm performance}

Board representation consist of executive and non-executive directors. Executive directors are responsible for the day-to-day affairs of the company. They have direct responsibility for business functions such as finance and marketing (Weir and Laing, 2001). They are full time employees of the company and have clearly defined roles and responsibilities. Several studies support the view that executive directors, who have better access to quality information, make superior decisions (Shakir, 2008; Boyd, 1994). Muth and Donaldson (1998) compared the predictions of agency theory with that of stewardship theory and found support for stewardship theory being a good model of reality. Firms with boards consisting of a greater number of non-executive directors (representing agency theory perspective), perform worse than firms with boards with less number of external directors (Kyereboah-Coleman et al., 2005; Yemack, 1996; Bhagat and Black, 1998). Agrawal \& Knoeber (1996) suggests that board expansion for political reasons often results in too many outsiders on the board, which does not help performance. Rashid (2009) finds that the outside directors cannot add any value as they do not have any supervisory position in the board. As such, some support exists for the stewardship perspective both conceptually (Subramanian, 2018; Davis et al., 1997) and also empirically (Bhagat \& Black, 1998).

But unlike non-executive directors, executive directors are not in a strong position to monitor or discipline the CEO (Daily and Dalton, 1993). It is therefore important that, there is a mechanism to monitor the actions of the CEO and executive directors and to ensure that they pursue shareholder interest. Dare (1993) explains that non-executive directors are effective monitors when inquiring on firm's strategy related questions. They are able to provide independent judgment when dealing with the executive directors in areas such as pay awards, executive director appointments and dismissals. If non-executive directors were effective monitors, this should result in improved corporate performance. However, studies have found that this is not to be the case (Rashid, 2018; Rashid et al., 2012; Bhagat and Black, 1998). In fact, they found a negative relationship between the proportion of outside directors and corporate performance.

H1: Firms with higher presence of non-executive directors are associated with improved performance, than firms with lower presence of non-executive directors

\subsection{Non-executive independent directors and firm performance}

The board of directors has the formal authority to ratify management initiatives, to evaluate managerial performance and to allocate rewards and penalties to management on the basis of criteria that reflect shareholders' interests. Therefore, the extent of true board independence is often considered as an important driver of 'good' corporate governance. Consistent with agency theory, a board comprising of independent directors are more likely to provide an effective oversight of the firm's CEO and other executive directors. Independent directors are generally believed to be more effective in protecting shareholders' interests by being impartial and is seen as a panacea to challenging issues of corporate governance, resulting in higher firm performance (Avci et al., 2018; Baysinger and Hoskisson, 1990). In most countries, the code of corporate governance includes special provisions for independent director appointments.

In an analysis of family controlled firms in the USA, Anderson and Reeb (2004) provide evidence that when the divergence of interests between family- and outside shareholder interests becomes large and costly, independent directors can intervene to protect the interests of all shareholders. Using a sample of the Standard \& Poor's 500 firms they show that the proportion of independent directors on a family-controlled firm's board is positively associated with performance measured by Tobin's Q, whereas the affiliated directors provide a negative impact on performance. The results presented, in the study by Rouf (2011) based on Bangladesh non-financial firms, suggest that board independent director presence is positively significant with firm performance. Several other researchers have also noted a positive relationship between independent outside directors' representation and firm performance (Barnhart and Rosenstein, 1998; Pearce and Zahra, 1992).

H2: Firms with higher presence of independent non-executive directors are associated with improved performance than firms with lower presence of independent non-executive directors 


\section{Results}

\subsection{Data description}

The number of non-executive directors on the boards, indicated a mean (standard deviation) of $66 \%(23.5 \%)$, with a range between $4.8 \%$ and $100 \%$. On average, the companies are in compliance with the code of governance based on suggestions made by Cadbury Committee (1992) that if the board is to become effective the non-executive directors should have a sufficient representation. The Table 1(a) below summarizes the representation of nonexecutive directors in the sample during the period. The trend is similar to the overall representation of independent non-executive directors on the board as seen in Table 1(b).

Table 1 (a). Descriptive statistics -Non-executive directors

\begin{tabular}{|c|c|c|c|c|c|c|c|}
\hline Non-executive directors & Overall & $\mathbf{2 0 0 4}$ & $\mathbf{2 0 0 5}$ & $\mathbf{2 0 0 6}$ & $\mathbf{2 0 0 7}$ & $\mathbf{2 0 0 8}$ & $\mathbf{2 0 0 9}$ \\
\hline Mean & $\mathbf{6 6 . 0 2} \%$ & $66.24 \%$ & $65.11 \%$ & $66.07 \%$ & $64.92 \%$ & $66.28 \%$ & $67.48 \%$ \\
\hline Median & $\mathbf{7 0 . 7 3 \%}$ & $71.43 \%$ & $71.43 \%$ & $72.73 \%$ & $71.43 \%$ & $70.71 \%$ & $66.67 \%$ \\
\hline Standard Deviation & $\mathbf{2 3 . 4 8 \%}$ & $21.64 \%$ & $23.21 \%$ & $24.65 \%$ & $24.54 \%$ & $23.92 \%$ & $22.93 \%$ \\
\hline Minimum & $\mathbf{4 . 7 6 \%}$ & $0.00 \%$ & $0.00 \%$ & $0.00 \%$ & $0.00 \%$ & $14.29 \%$ & $14.29 \%$ \\
\hline Maximum & $\mathbf{1 0 0 . 0 0} \%$ & $100.00 \%$ & $100.00 \%$ & $100.00 \%$ & $100.00 \%$ & $100.00 \%$ & $100.00 \%$ \\
\hline
\end{tabular}

Table 1(b). Descriptive statistics - Independent non-executive directors

\begin{tabular}{|c|c|c|c|c|c|c|c|}
\hline $\begin{array}{l}\text { Independent Non-executive } \\
\text { Directors }\end{array}$ & $\begin{array}{c}\text { Overal } \\
1\end{array}$ & 2004 & 2005 & 2006 & 2007 & 2008 & 2009 \\
\hline \multirow{2}{*}{ Mean } & 23.27 & 16.68 & 17.21 & 21.52 & 23.85 & 28.15 & 32.21 \\
\hline & $\%$ & $\%$ & $\%$ & $\%$ & $\%$ & $\%$ & $\%$ \\
\hline \multirow{2}{*}{ Median } & 22.49 & 14.29 & 14.29 & 22.22 & 22.22 & 28.57 & 33.33 \\
\hline & $\%$ & $\%$ & $\%$ & $\%$ & $\%$ & $\%$ & $\%$ \\
\hline \multirow{2}{*}{ Standard Deviation } & 17.47 & 17.46 & 17.13 & 18.88 & 18.32 & 17.49 & 15.53 \\
\hline & $\%$ & $\%$ & $\%$ & $\%$ & $\%$ & $\%$ & $\%$ \\
\hline Minimum & $0.00 \%$ & $0.00 \%$ & $0.00 \%$ & $0.00 \%$ & $0.00 \%$ & $0.00 \%$ & $0.00 \%$ \\
\hline \multirow{2}{*}{ Maximum } & 66.47 & 57.14 & 57.14 & 75.00 & 71.43 & 71.43 & 66.67 \\
\hline & $\%$ & $\%$ & $\%$ & $\%$ & $\%$ & $\%$ & $\%$ \\
\hline
\end{tabular}

Companies reflect a growing trend of having increased independent non-executive directors on the board. As shown in the Table 1(b), the average number of board members who are independent non- executive is about $23.3 \%$, with a range between from $16.68 \%$ to $32.21 \%$ and is on rise from 2004 to 2009 across our sample. Average independent directors' representation has increased from an average of $17.01 \%$ in 2004 to $32.28 \%$ in 2009 . These suggest that firms have been encouraged for more non-executive independent directors' participation in their corporate boards with the introduction of new standards relevant to board independence under recent corporate governance reforms. As at 31st March 2009, we find more than $60 \%$ of the companies have complied with the regulations relevant to appointment of independent directors as proposed by new code of governance. According to the regulations, if the constitution of the board of directors includes only two non-executive directors, both such non-executive directors need to be 'independent'. In all other instances two or $1 / 3$ of non-executive directors appointed to the board of directors, whichever is higher shall be independent. The average board size was approximately 8 members, while the range was between four and thirteen members. The average firm size as measured by total assets and annual turnover was approximately US $\$ 16.2 \mathrm{~m}$ and US\$ $14.1 \mathrm{~m}$ respectively (US\$ $=$ 190LKR).

\subsection{Comparison of financial performance based on board composition}

The full sample was partitioned into two subsamples over the period under study, based on the average nonexecutive director ratio on the board (Figure 2). The firms with ratio higher than the sector average were separated from those firms with ratios lower than the sector average. Then the financial and market performance of each group was compared to establish difference in performance levels. Similarly, the sample was again partitioned based on the composition of board based on independent non-executive numbers and assessed against firms' performance. Non parametric tests were used because of the small sample size and since ROE, ROA, MBVR and PE ratios were not distributed normally. 


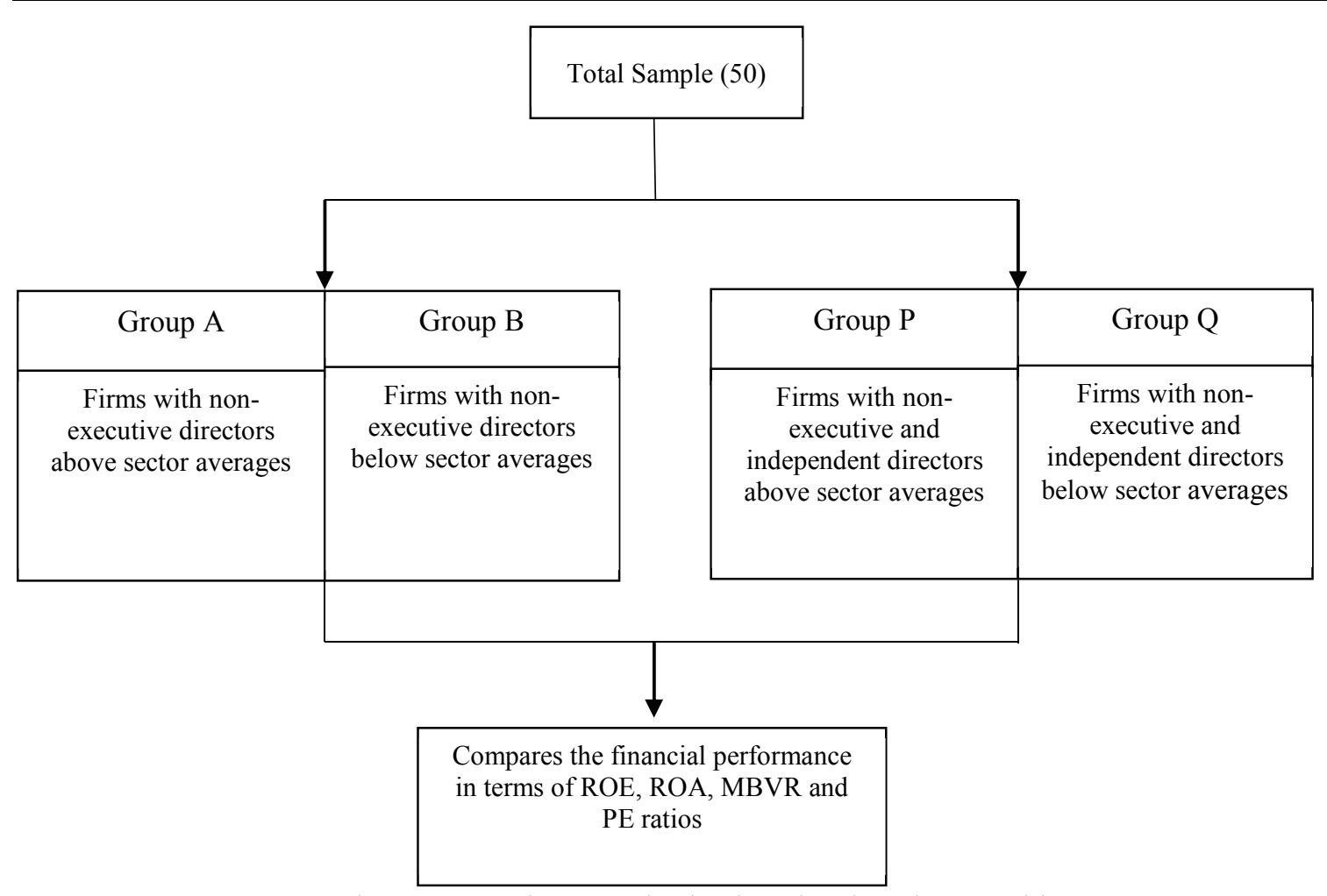

Figure 2. Sample categorization based on board composition

Tables 2(a), 2(b) summarizes the results of the tests and compares the mean rank of dependent performance variables for each group categorized based on average director board composition from 2004 - 2009. Hypothesis were tested at $95 \%$ confidence level.

Table 2(a). Comparison of performance based on board composition

\begin{tabular}{|c|c|c|c|c|c|c|c|c|}
\hline & $\begin{array}{l}\text { Dependen } \\
\text { t Variable }\end{array}$ & & & \multicolumn{2}{|l|}{ ROE } & & \multicolumn{2}{|l|}{ ROA } \\
\hline $\begin{array}{l}\text { Independent } \\
\text { Variable }\end{array}$ & & $N$ & Absolute & $\begin{array}{l}\text { Mean } \\
\text { Rank }\end{array}$ & Z Value & Absolute & $\begin{array}{l}\text { Mean } \\
\text { Rank }\end{array}$ & Z Value \\
\hline \multirow{2}{*}{$\begin{array}{l}\text { Non-executive } \\
\text { director }\end{array}$} & Group - A & 28 & $11.25 \%$ & 24.32 & \multirow{2}{*}{-0.65} & $5.75 \%$ & 23.68 & \multirow{2}{*}{-1.00} \\
\hline & Group - B & 22 & $14.13 \%$ & 27.00 & & $7.38 \%$ & 27.82 & \\
\hline \multirow{2}{*}{$\begin{array}{l}\text { Independent } \\
\text { Non-executive } \\
\text { director }\end{array}$} & Group - A & 21 & $10.81 \%$ & 22.14 & \multirow{2}{*}{-1.39} & $5.55 \%$ & 22.33 & \multirow{2}{*}{-1.32} \\
\hline & Group - B & 29 & $13.76 \%$ & 27.93 & & $7.13 \%$ & 27.79 & \\
\hline
\end{tabular}

Note: Group A-above average; Group B - below average

Table 2(b). Comparison of performance based on board composition

\begin{tabular}{|c|c|c|c|c|c|c|c|c|}
\hline \multirow{2}{*}{$\begin{array}{l}\text { Independent } \\
\text { Variable }\end{array}$} & \multirow[t]{2}{*}{$\begin{array}{l}\text { Dependent } \\
\text { Variable } \\
\end{array}$} & \multirow[b]{2}{*}{$N$} & \multirow[b]{2}{*}{ Absolute } & \multicolumn{2}{|l|}{ MBVR } & \multirow[b]{2}{*}{ Absolute } & \multicolumn{2}{|l|}{ PE } \\
\hline & & & & $\begin{array}{c}\text { Mean } \\
\text { Rank }\end{array}$ & Z Value & & $\begin{array}{r}\text { Mean } \\
\text { Rank }\end{array}$ & Z Value \\
\hline \multirow{2}{*}{$\begin{array}{l}\text { Non-executive } \\
\text { director }\end{array}$} & Group - $A$ & 28 & 1.337 & 24.98 & -0.10 & 10.054 & 24.79 & -0.12 \\
\hline & Group - B & 22 & 1.295 & 25.02 & & 9.939 & 25.29 & \\
\hline \multirow{2}{*}{$\begin{array}{l}\text { Independent } \\
\text { Non-executive } \\
\text { director }\end{array}$} & Group $-A$ & 21 & 1.448 & 26.45 & -0.59 & 10.974 & 27.55 & \multirow{2}{*}{-1.04} \\
\hline & Group - B & 29 & 1.229 & 27.93 & & 8.559 & 27.79 & \\
\hline
\end{tabular}

Note: Group P - above average; Group $Q$ - below average

Contrary to expectation, the results in absolute figures show that companies that maintained higher board representation of non-executive directorates above other companies in the same sector have performed comparatively poorly than those with a lower board representation of non-executive directorates. As seen in Table 3(a) and 3(b), this is true for both financial indicators, ROE and ROA, and one of the market performance measures, MBVR (Market to Book Value). The PE ratio, however, indicates that the market is valuing those companies that 
maintain a higher board representation of non-executive directors, at a premium. However, the differences in all cases are not statistically significant. In order to further verify the findings, the initial sample was again partitioned into two groups based on average performance levels of ROE, ROA, MBVR and PE ratios respectively. Then for each of the indicators, it was verified whether board composition of non-executive directors and board composition of independent non-executive directors and was each significantly different for the two respective separate groups (P \& Q).

Table 3(a). Board composition comparison based on performance

\begin{tabular}{|c|c|c|c|c|c|c|c|}
\hline \multirow{2}{*}{$\begin{array}{l}\text { Independent } \\
\text { Variable }\end{array}$} & \multirow{2}{*}{ Grouping } & \multirow{2}{*}{ Absolute } & \multicolumn{2}{|c|}{ Non-Executive\% } & \multirow{2}{*}{ Absolute } & \multicolumn{2}{|c|}{$\begin{array}{l}\text { Independent and } \\
\text { Non-Executive \% }\end{array}$} \\
\hline & & & Mean Rank & Z Value & & Mean Rank & Z Value \\
\hline \multirow{2}{*}{ ROE } & Group $-P$ & $62.25 \%$ & 23.88 & \multirow{2}{*}{-0.92} & $22.94 \%$ & 25.74 & \multirow{2}{*}{-0.14} \\
\hline & Group $-Q$ & $67.73 \%$ & 27.74 & & $23.89 \%$ & 25.17 & \\
\hline \multirow{2}{*}{ ROA } & Group $-P$ & $63.21 \%$ & 24.83 & \multirow{2}{*}{-1.17} & $22.37 \%$ & 26.48 & \multirow{2}{*}{-0.28} \\
\hline & Group $-Q$ & $69.14 \%$ & 29.83 & & $24.04 \%$ & 27.67 & \\
\hline \multirow{2}{*}{ MBVR } & Group $-P$ & $66.57 \%$ & 24.95 & \multirow{2}{*}{-0.02} & $23.67 \%$ & 26.45 & \multirow{2}{*}{-0.62} \\
\hline & Group $-Q$ & $63.95 \%$ & 25.04 & & $22.52 \%$ & 23.91 & \\
\hline \multirow{2}{*}{ PE } & Group -P & $64.33 \%$ & 25.69 & \multirow{2}{*}{-0.56} & $25.60 \%$ & 29.96 & \multirow{2}{*}{-1.27} \\
\hline & Group $-Q$ & $66.15 \%$ & 28.09 & & $21.35 \%$ & 24.55 & \\
\hline
\end{tabular}

The results for board composition based on non-executive representation, under this scenario reveal similar results as the results based on the financial indicators. That is companies with higher ROE, ROA are associated with lower non-executive representation. On the market indicators, MVBR in this case is associated with higher representation rather than $\mathrm{PE}$ ratio previously.

Table 3(b). Board composition comparison based on performance

\begin{tabular}{|l|l|l|l|}
\hline & Grouping & \multicolumn{2}{|l|}{ Board Size } \\
\hline $\begin{array}{l}\text { Independent } \\
\text { Variable }\end{array}$ & & Mean Rank & \multirow{2}{*}{ Z Value } \\
\hline \multirow{2}{*}{ ROE } & Group $-P$ & 24.88 & \multirow{2}{*}{-0.35} \\
\hline \multirow{2}{*}{ ROA } & Group $-Q$ & 26.36 & \\
\hline \multirow{3}{*}{ MBVR } & Group $-P$ & 27.08 & \multirow{2}{*}{-0.05} \\
\cline { 2 - 4 } & Group $-Q$ & 26.89 & \\
\hline \multirow{2}{*}{ PE } & Group $-P$ & 24.64 & \multirow{2}{*}{-0.15} \\
\cline { 2 - 4 } & Group $-Q$ & 25.27 & \multirow{2}{*}{-3.02} \\
\hline
\end{tabular}

When you evaluate performance on board composition based on members being independent non-executive directors, the absolute figures on ROE indicate that higher representation has resulted in better performance outcome. This is however, not the case for ROA. But there is some inconsistency on the part of firms categorized based on ROE. On both market measures, MVBR and PE ratio, the valuation for firms with higher independent non-executive representation, is higher. However, again in all the above cases, they are not statistically significant. The study extends the analysis by using event study methodology to evaluate whether the results from previous sections are robust. Firms that increased their independent board representation were isolated, and evaluated whether there is a significant difference in performance between the pre and post change periods. Results in Table 4, indicate that on average, a slight increase in MBVR and PE ratios is associated with the increase in independent directors implying that compliance with the new regulation of appointing more independent directors to the board resulted in an improvement in market performance, compared to firms with lower representation of independent directors. 
Table 4. Performance comparison based on pre and post changes to board composition

\begin{tabular}{|l|l|l|l|l|}
\hline & & Absolute & Mean Rank & Z Value \\
\hline \multirow{2}{*}{ ROE } & Before & 0.15 & 15.18 & \multirow{2}{*}{-0.437} \\
\cline { 2 - 4 } & After & -2.14 & 13.82 & \\
\hline \multirow{2}{*}{ ROA } & Before & -0.48 & 16.94 & \multirow{2}{*}{-0.264} \\
\cline { 2 - 4 } & After & -1.15 & 16.06 & \\
\hline \multirow{2}{*}{ MBVR } & Before & -0.16 & 14.36 & \multirow{2}{*}{-0.092} \\
\cline { 2 - 5 } & After & -0.05 & 14.64 & \multirow{2}{*}{-0.505} \\
\hline \multirow{2}{*}{ PE } & Before & -2.74 & 13.71 & \\
\cline { 2 - 5 } & After & -1.33 & 15.29 & \\
\hline
\end{tabular}

As shown previously, a slight decrease in firm performance in terms of ROE and ROA in the post change period compared to the pre change period is noticed. Again, the results are statistically insignificant. According to the results of all the three methodologies tested in the study, we find a negative but insignificant relationship between traditional board independence, in the form of non-executive directors and firms' financial or market performance. This is consistent with the outcomes of the studies by Rashid (2018), Fuzia et al. (2016), Laing and Weir (1999) who reported a negative relationship between the proportion of independent directors and performance. However, the study found evidence to indicate that the appointment of independent non-executive directors is perceived positively in the marketplace as indicated by enhanced values for both market to book value and price to earnings ratios. The same result was not seen though, in the other market performance indicators analyzed. Though results are not significant, these findings provide support for early research done by Zajac and Westphal (1996); Hermalin and Weisbach (1988); Shivdasani and Yermack (1999).

\section{Conclusion}

The study aimed to examine if board composition in the form of representation of non- executive and independent non-executive independent directors may influence the firms' financial and market performance in the context of a developing country like Sri Lanka. The solutions proposed to improve corporate governance mechanisms adopted in developed countries, may not necessarily work in countries where markets are small, a few large shareholders dominate ownership, and regulation and enforcement is lax. The empirical findings suggest that contrary to expectation, there was no evidence to link performance enhancement with companies having a high proportion of independent non-executive directors. In absolute figures, higher ROE and ROA was recorded in companies with lower number of independent non-executive directors. However, on the market indicators, MVBR and $\mathrm{PE}$ ratio, the market seemed to allocate a premium for those companies having a higher proportion of independent non-executive directors. It should be noted, that the differences were not statistically significant. The evidence suggests that good corporate governance is important for increasing investor confidence and market liquidity which can influence enhance firm value.

It is widely believed that non-executive directors of a firm play important functions of monitoring and advising. But it is quite interesting to investigate why the outside and outside independent directors cannot influence the firm performance as desired. According to a survey done by KPMG (2007), majority of the respondents feel that independent directors do not adequately challenge the executive directors and management in the process of discharging their governance responsibilities. The incidence of multiple directorships in Sri Lankan listed companies is relatively high due to related entities, which share common directors and high institutional ownership (Peter et al., 2010; Senaratne and Gunaratne, 2007; Manawaduge et al., 2009). Ownership is highly concentrated with the largest shareholder having almost forty four percent of the firm, whereas the first ten largest shareholders' ownership average is as high as eighty percent. Corporate control is therefore often in the hands of a few individuals, families or corporate groups who hold the majority of ownership. Evidence suggests that that a very high percentage of shares of companies in the Sri Lankan stock market is owned by institutional investors (Manawaduge et al., 2009). The candidate pool for no-executive director positions are relatively limited and the majority shareholders opt for candidates that they already have a relationship with. Therefore, it is common to see the same set of candidates sitting on multiple boards of other listed companies. This significantly increases the workload of these directors and therefore may not be able to dedicate the required time to adequately perform their director roles, especially regarding their monitoring duties (Peter et al., 2010; Kiel and Nicholson, 2006; Fich and Shivdasani, 2006; Jiraporn et al., 2007).

Another possible reason could be the interlocking directorates that occur when directors of two companies simultaneously serve on each other's boards to protect their self-interests. In developing countries like Sri Lanka, where ownership is highly concentrated, this is regarded to be fairly common (Peter, 2015). It is mainly due to the fact that few large investors hold a significant amount of shares in many listed companies and the possibility of 
appointing persons loyal to them. The one-tier board structure in the corporate sector may also inhibit the ability of the independent directors to play the expected supervisory role on the board.

The current regulations on corporate governance provides existing elected directors to make new appointments to the board. Therefore, there is provision for new appointments to be made based on the close relationship of majority owners and relationship with the existing board members. The legislation is also lax as there is no guidelines on the minimum qualification and experience required from a nominee.

The evidence found in this study, is more in line with the stewardship theory, where inside directors may have inside information of the firm versus the external directors (Nicholson and Kiel, 2007). Such information asymmetry may have reduced the control role of the external directors in the firm. or they may have failed to perform their assigned tasks due to having lack of appropriate support by the insiders. Bealsy (1996) and Ahmed et al., (2007) found that higher outside director shareholding is associated with a lower incidence of financial statement fraud which reduce agency cost. But too much shareholding would erode the independence of the directors. So establishing a proper incentivizing system to appreciate and encourage their active involvement in decision making is needed. Given the restrictions seen in a developing country context, where limited number of companies, cross holding of shares, ownership is closely held, the mere adherence to increase non-executive director representation, may not necessarily improve the governance structure. Allowing cumulative voting, where minority shareholders will have a greater role in selecting board members, defining the minimum qualification and experience required, restricting the number of companies where a single person can hold board positions, and designing incentive structures to align directors' interests with shareholders' interests could be incorporated.

\section{References}

Abdur Rouf. (2011). The role of CEO, Board Composition and Firm Performance: An empirical study of listed companies in Bangladesh. Indian Journal of Commerce and Management Studies

Agrawal, A. and C.R. Knoeber. (1996). Firm performance and mechanisms to control agency problems between managers and shareholders. Journal of Financial and Quantitative Analysis

Anderson, R. C., Mansi, S. A., \& Reeb, D. M. (2004). Board Characteristics, Accounting Report Integrity, and Cost of Debt. Journal of Accounting and Economics

Anwer S. Ahmed and Scott Duellman. (2007). Accounting Conservatism and Board of Director Characteristics: An Empirical Analysis. Journal of Accounting and Economics, vol. 43, issue 2-3, 411-437

Avci, S. Burcu, Schipani, Cindy A. and Seyhun, H. Nejat. (2018). The Elusive Montoring Function of Independent Directors. U. of Pennsylvania Journal of Business Law, Vol. 21:2

Baysinger, B. D. \& Hoskisson, R. E. (1990). The composition of boards of directors and strategic control: Effects on corporate strategy. Academy of Management Review, 15(1), 72-87

Barnhart Scott W, Stuart Rosenstein. (1998). Board Composition, Managerial Ownership, and Firm Performance: An Empirical Analysis. The Financial Review, Vol. 33, Issue 4

Bhagat S, and Black B.S. (1998). The uncertain relationship between board composition and firm performance. In K. Hopt, M. Roe, and E. Wymeersch, eds., Corporate Governance: The State of the Art and Emerging Research. Oxford University Press, Oxford, 301-326.

Boyd, B. K. (1994). Board control and CEO compensation. Strategic Management Journal, 15, 5, pp.335-344

Cadbury, A. (1992). Report of the Committee on the Financial Aspects of Corporate Governance. London: Gee Publishing

C. H. Ponnu. (2008). Corporate Governance Structures and the Performance of Malaysian Public Listed Companies, International Review of Business Research Papers, Vol. 4 No.2, pp.217-230

Coles, J. W. \& Hesterly, W. S. (2000). Independence of the Chairman and Board Composition: Firm Choices and Shareholder Value. Journal of Management.

Daft, R. (2006). Organisation Theory and Design. New York: South-Western College.

Daily C. M., Dalton D. R. (1993). Boards of directors, leadership and structure: control and performance implications. Entrepreneurship Theory Pract., 17: 65-81

Dare P. (1993). Corporate governance - an investors perspective. The Treasurer, pp. 26-29

Dimitrov, V., and Jain, P. C. (2008). The value relevance of changes in financial leverage beyond growth in assets and GAAP earnings. Journal of Accounting, Auditing and Finance, 23(2), 191-222

Donaldson, L. (1990). The ethereal hand: Organizational Economics and Management Theory. Academy of Management Review, 15: 369-381

Donaldson, L., \& Davis, J. H. (1991). Stewardship theory or agency theory: CEO governance and shareholder returns. Australian Journal of Management, 16(1), 49-64

Donaldson, L., \& Davis, J. H. (1994). Boards and Company Performance - Research Challenges the Conventional Wisdom. Corporate Governance: An International Review, 2(3), 65-91

Donaldson, T., \& Preston, L. E. (1995). The Stakeholder Theory of the Corporation: Concepts, Evidence, and Implications. Academy of Management Review, 20(1),65-91 
Fama, E. F. 1980, Agency problems and the theory of the firm. Journal of Political Economy, 88, 288-307

Fama, E. F. and M. C. Jensen. (1983a). Agency problems and residual claims. Journal of Law and Economics, 26, 301-326

Fama E. F. and Jensen M. C. (1983b). Separation of Ownership and Control. J. Law Econ., 6: 301-325

Fich and Shivdasani. (2006). Are Busy Boards Effective Monitors? The Journal of Finance, Vol. LXI, No. 2

Freeman, R. E. (1984). Strategic Management: A Stakeholder Approach. Boston: Pitman

Fuzia, Sharifah Faatihah Syed, Halima, Syahrina 'Adliana Abdul, Julizaerma M. K. (2016). Board Independence and Firm Performance. Procedia Economics and Finance, 37, 460 - 465

Hermalin, B. and Weisbach, M. (1988). The Determinants of Board Composition. RAND Journal of Economics, 19 (4), 589-606

Hermalin, B. E., \& Weisbach, M. S. (2003). Boards of Directors as an Endogenously Determined Institution: A Survey of the Economic Literature. Economic Policy Review

Hillman, A. J., Cannella Jr. A. A., and Paetzold, R. L. (2000). The Resource Dependence Role of Corporate Directors: Strategic Adaption of Board Composition in Response to Environmental Change. Journal of Management Studies, 37, 2, pp.235-255

Jensen, M. C., \& Meckling, W. (1976). Theory of the Firm: Managerial Behavior, Agency Costs and Ownership Structure. Journal of Financial Economics, October, V.3, 4, pp. 305-360

Jiraporn, P., Y. S. Kim, and W. N. Davidson. (2007). Multiple Directorships and Corporate Diversification. Journal of Empirical Finance, 2008, vol. 15, issue 3, 418-435

Joh, S. W., Jung, J. (2012). The effects of outside board on firm value in the emerging market from the perspective of information transaction cost. Asia-Pacific Journal of Financial Studies, 41 (2) (2012), pp. 175-193

Jonsson, E. I. (2005). The Role Model of the Board: A Preliminary Study of the Roles of Icelandic Boards. Corporate Governance: An International Review, 13 (5), 710-717

Johnson, J. L., Daily, C. M., \& Ellstrand, A. E. (1996). Boards of Directors: A Review and Research Agenda. Journal of Management, 22(3), 409-438

Kaplan, S. N., \& Minton, B. A. (1994). Appointments of Outsiders to Japanese Boards: Determinants and Implications for Managers. Journal of Financial Economics, 36(2), 225-258.

Kiel, G., \& Nicholson. G. (2003). Board Composition and Corporate Performance: How the Australian experience informs contrasting theories of corporate governance. Corporate Governance: An International Review, 11(3), 189-205.

Kiel, Geoffrey \& Nicholson, Gavin. (2006). Multiple Directorships and Corporate Performance in Australian Listed Companies. Corporate Governance: An International Review, 14(6), pp. 530-546

KPMG. (2007). Corporate Governance Survey in Sri Lanka, Practices and Developments of Corporate Governance.

Kyereboah-Coleman and Biekpe. (2005). The Relationship Between Board Size, Board Composition, CEO Duality and Firm Performance: Experience From Ghana. Corporate Ownership \& Control, 4(2), 114-122

Laing, D. and C. Weir. (1999). Governance structures, size and corporate performance in UK firms, Management Decision 37(5), 457-464.

Lynall M. D., Golden B. R., Hillman A. J. (2003). Board composition from adolescence to maturity: A multitheoretic view. Academy of Management Review, 28(3): 416-431

Martín, C. José García \& Herrero, Begoña, (2018). Boards of directors: composition and effects on the performance of the firm. Economic Research-Ekonomska Istraživanja, 31:1, 1015-1041

Manawaduge Athula, De Zoysa, Anura. and Rudkin, Kathy. (2009). Performance Implication of Ownership Structure and Ownership Concentration: Evidence from Sri Lankan Firms. Sixth Conference of Performance Measurement Association, Otago University, New Zealand

McGuire J. B., Sundgren A, Schneeweis T. (1988). Corporate social responsibility and firm financial performance.” Acad. Manage. J., 31(4): 854-872

McIntyre, M. L., Murphy S. A. and Mitchell P. (2007). The top team: examining board composition and firm performance. Corporate Governance, Vol. 7 No. 5, pp. 547-561

Muth, M. M. and Donaldson, L. (1998). Stewardship Theory and board structure; a contingency approach, corporate governance. Scholarly Research and Theory Papers, Blackwell Publishers

Pearce II, J. A., \& Zahra, S. A. (1992). Board Composition from a Strategic Contingency Perspective. Journal of Management Studies, 29(4), 411-438

Penrose, E. T. (1995). The Theory of the Growth of the Firm. 3rd ed. Oxford University Press, Oxford

Pfeffer, J., \& Salancik, G. (1978). The External Control of Organisations: A Resource Dependence Perspective. New York: Harper and Row

Rashid. A. (2009). Board Composition, Board Leadership Structure and Firm performance: Evidence from Bangladesh. AFAANZ Annual Conference

Rashid, A. De Zoysa, S. Lodh, K. Rudkin. (2012). Reply to "response: Board composition and firm performance: Evidence from Bangladesh a sceptical view”. Australasian Accounting Business and Finance Journal, 6 (3), 
pp. 121-131

Rashid, A. (2018). Board independence and firm performance: Evidence from Bangladesh. Future Business Journal, Volume 4, Issue 1, Pages 34-49

Roberts, J., T. McNulty. (2005). Beyond Agency Conceptions of the Work of the Non- Executive Director: Creating Accountability in the Boardroom. British Journal of Management, 16(s1): S5-S26

Rosenstein, S. and J. G. Wyatt. (1990). Outside Directors, Board Independence, and Shareholder Wealth. Journal of Financial Economics, 26, pp. 175-192

Senaratne, S. and P. S. M. Gunaratne. (2007). Ownership Structure and Corporate Governance of Sri Lankan Listed Companies. The $4^{\text {th }}$ International Conference on Business Management, Faculty of Management Studies and Commerce, University of Sri Jayewardenepura, Sri Lanka

Shakir, R. (2008). Board Size, Board Composition and Property Firm Performance. Pacific Rim Property Research Journal, Volume 14, 2008 - Issue 1

Shivdasani, A. and Yermack, D. (1999): CEO involvement in the selection of new board members: An empirical analysis. Journal of Finance, 54, 1829-1853

Subramanian, S. (2018). Stewardship Theory of Corporate Governance and Value System: The Case of a Familyowned Business Group in India. Indian Journal of Corporate Governance, Volume: 11 issue: 1, page(s): 88102

Weir C, Laing D (2001). Governance Structures, Director Independence and Corporate Performance in the UK. Euro. Bus. Rev., 13(2): 86-95

Weir, C., Laing, D., \& McKnight, P. J. (2002). Internal and External Governance Mechanisms: Their Impact on the Performance of Large UK Public Companies. Journal of Business Finance \& Accounting, 29(5\&6), 579_ 611

Zajac, Edward J. \& Westphal, James D. (1996). Director reputation, CEO board power and the dynamics of board interlocks. Administrative Science Quarterly, 41 (3): 507-529 